\title{
SIKAP BAHASA MASYARAKAT TUTUR BAHASA BALI KOTA SINGARAJA
}

\author{
D.P. Ramendra \\ Fakultas Bahasa dan Seni \\ Universitas Pendidikan Ganesha \\ E-mail: dewaramendra@yahoo.com
}

\begin{abstract}
Abstrak
Penelitian ini bertujuan untuk memaparkan sikap bahasa masyarakat tutur bahasa Bali Kota Singaraja. Untuk mencapai tujuan itu, penelitian ini menerapkan desain survei dan sebagaimana desain itu pada umumnya, menggunakan angket dan pedoman wawancara sebagai alat pengumpulan data. Penelitian ini menggunakan 285 orang sebagai sample/responden yang dipilih secara disproportionate stratified purposive sampling 'sampel nonacak berlapis-takproporsional'. Responden itu juga diklasifikasikan menjadi 24 kelompok menurut variabel wangsa, status pekerjaan, umur, dan gender. Hasil penelitian menunjukkan bahwa sikap bahasa responden cenderung untuk berbeda menurut wangsa, tetapi tidak menurut status pekerjaan, umur, dan gender. Sikap terhadap kode kasar dan kode biasa pada penutur triwangsa dan jaba cenderung untuk tidak menunjukkan perbedaan, yakni netral/sedang dan positif secara berurutan. Akan tetapi, sikap terhadap kode alus berbeda: pada triwangsa sikap terhadap kode itu berkategori sangat positif, sedangkan pada jaba sikap yang ditunjukkan tergolong positif. Di samping itu, sikap itu juga menunjukkan penurunan secara konsisten dari komponen kognitif ke konatif terutama pada triwangsa. Dari penurunan konsisten ini dapat diramalkan bahwa penggunaan bahasa Bali secara nyata akan cenderung rendah.
\end{abstract}

Kata kunci: sikap bahasa, masyarakat tutur, dan tingkat tutur.

\begin{abstract}
This research aimed at describing the language attitude of Balinese speech community in Singaraja city. To achieve the purpose, this reseach applied survey design and as a survey design in general, used questionnairre and interview guide as instruments for data collection. This research took 285 samples/respondents chosen through disproportionate stratified purposive sampling. The respondents were also divided into 24 groups according to wangsa, occupation status, age, and gender. The result of the research shows that the respondents' language attitude tend to be different according to wangsa, but not according to occupation status, age, and gender. The attitude towards kasar and biasa code by triwangsa and jaba speakers tends not to be different, that is, netral/moderate and positive simultaneously. However, the attitude towards alus code is different: it shows very positive attitude on triwangsa, whereas it shows positive attitude on jaba. Besides, the language attitude also seems to fall consistently from cognitive to conative
\end{abstract}


component especially on triwangsa. From the fall it could predicted that the use of Balinese in reality will tend to be low.

Keywords: language attitude, speech community, and speech levels.

\section{PENDAHULUAN}

Ada sejumlah ragam klasifikasi tingkat tutur bahasa Bali (Suastra, 1998). Akan tetapi, perbedaan cara itu tidak pernah menjadi masalah karena itu hanya terkait dengan masalah detail, apalagi dasar dari tolak ukur klasifikasi itu adalah sama, yakni rasa bahasa. Pada penelitian ini ragam tingkat tutur bahasa Bali diklasifikasikan menjadi tiga, yakni ragam (kode) kasar, ragam (kode) biasa, dan ragam (kode) alus. Secara tradisional kode kasar seharusnya digunakan pada saat marah, pada percakapan yang sangat akrab, atau pada binatang; kode biasa seharusnya digunakan di antara penutur jaba atau oleh penutur triwangsa kepada penutur jaba; sedangkan, kode alus digunakan oleh penutur jaba untuk bercakap-cakap dengan petutur triwangsa atau di antara penutur triwangsa.

Penggunaan bahasa Bali oleh masyarakat tutur Kota Singaraja sering mendapat tanggapan negatif dari masyarakat tutur nonKota Singaraja. Laksana (2009) mencontohkan bahwa seorang penutur dari Gianyar yang bersekolah di Kota Singaraja pada sering kaget karena ditegur dengan menggunakan kode kasar oleh temantemannya dari Singaraja. Laksana selanjutnya mengungkapkan bahwa penutur muda Kota Singaraja memang sering menggunakan kata-kata kasar dalam bertutur sapa. Wingarta (2009) juga mendukung hasil pengamatan Laksana tersebut dengan memaparkan bahwa penggunaan bahasa di Kota
Singaraja cenderung untuk dilihat kasar oleh masyarakat Bali yang lainnya. Sebagai akibatnya, muncul stereotip bahwa masyarakat tutur Kota Singaraja "kasar-kasar".

Terlepas dari apakah itu benar atau tidak, stereotip dan penggunaan tingkat tutur bahasa Bali di masyarakat tutur Kota Singaraja menarik untuk dikaji. Salah satu pertanyaan yang dapat dikaji adalah bagaimanakah masyarakat itu mempersepsi dan merasakan bahasa Bali. Dengan demikian, penelitian tentang sikap bahasa menjadi penting untuk dilakukan.

Sikap dapat diartikan sebagai evaluasi seseorang terhadap sesuatu atau seseorang yang dapat menimbulkan perasaan suka dan tidak suka terhadap sesuatu atau seseorang itu (Baron dan Byrne, 2002: 120). Dengan demikian, sikap bahasa merupakan suatu sikap yang objeknya adalah bahasa. Struktur sikap bahasa, seperti juga sikap-sikap yang objeknya lain, mengikuti skema triadik yang terdiri atas tiga komponen yang saling terkait, yaitu komponen kognitif, komponen afektif dan komponen konatif (Garret, 2010: 23; dan Azwar, 1995: 23-24). Komponen kognitif atau pengetahuan meliputi semua jenis pengetahuan seseorang tentang objek sikap. Kepercayaan itu meliputi kepercayaan atau pengetahuan mengenai benar atau salah, baik atau buruk, dan diinginkan atau tidak diinginkan. Sekali suatu kepercayaan terbentuk, maka itu akan menjadi dasar bagi pengetahuan 
seseorang tentang apa yang bisa diharapkan dari objek tertentu. Komponen afektif atau evaluatif bisa diartikan sebagai penilaian atau nilainilai emosi yang terkait dengan kepercayaan. Seseorang bisa merasa senang atau tidak senang terhadap suatu objek sikap melalui rasa yang ditimbulkan oleh kepercayaankepercayaan mengenai objek sikap tersebut. Selanjutnya, komponen konatif atau perilaku bisa diartikan sebagai kecenderungan untuk bertindak. Komponen konatif itu dipengaruhi oleh komponen kognitif dan afektif. Dengan rumusan lain dapat diungkapkan bahwa kepercayaan yang sesuai dan nilai-nilai emosi (rasa) yang menyertainya diwujudkan menjadi kehendakkehendak perilaku.

Selain itu, sikap bahasa juga memiliki tiga dimensi, yakni kesetiaan bahasa, kebanggaan bahasa, dan kesadaran akan norma penggunaan bahasa. Kesetiaan bahasa mengisyaratkan keteguhan atau ketaatan untuk menggunakan, menjaga dan mempertahankan suatu bahasa. Hal itu juga termasuk mencegah masuknya pengaruh lain ke dalam bahasa tersebut. Kebanggaan biasanya terwujud pada sikap menghargai suatu bahasa. Rasa puas itu juga mendorong suatu masyarakat pengguna bahasa untuk mengembangkan bahasanya dan menjadikannya lambang identitas dan kesatuan. Selanjutnya, kesadaran akan norma penggunaan bahasa menyiratkan pemahaman tentang penggunaan bahasa secara baik dan benar. Pemahaman tersebut selanjutnya membuat seseorang dapat menggunakan bahasa secara cermat dan santun.
Ketiga dimensi sikap bahasa tersebut berperan penting bagi kebertahanan suatu bahasa. Jika ketiganya hadir bersamaan dengan intensitas yang tinggi pada suatu masyarakat pengguna bahasa, itu berarti bahwa sikap bahasa masyarakat tersebut positif. Selanjutnya, bahasa tersebut akan memiliki tingkat kemandirian dan kebertahanan yang tinggi karena digunakan dengan setia, bangga, dan taat azas. Sebaliknya, jika ketiga dimensi itu lemah, sikap bahasa masyarakat juga menjadi negatif. Oleh karena itu, kemandirian dan kebertahanan bahasa pun menjadi lemah.

Lebih lanjut, Baker (dalam Katubi, 2010) menjelaskan bahwa penelitian mengenai sikap bahasa berguna bagi pengumpulan informasi tentang ukuran kesehatan bahasa dalam kaitannya dengan isu kebertahanan bahasa; indikator pikiran, kepercayaan, dan keinginan masyarakat terkait dengan bahasa mereka; dan indikator keberhasilan bagi keberhasilan implementasi kebijakan. Selain itu, Fasold (1984) menambahkan bahwa arah perubahan bunyi dipengaruhi oleh sikap bahasa dari suatu masyarakat, dalam artian bahwa sikap bahasa ikut berperan pada dinamika bahasa. Sebagai tambahan, sikap bahasa memengaruhi cara guru untuk berhubungan dengan siswa dan keberhasilan siswa dalam mempelajari suatu bahasa, khususnya bahasa kedua atau bahasa asing.

Berhubungan dengan paparan di atas, artikel ini berupaya untuk memaparkan sikap masyarakat tutur bahasa Bali Kota Singaraja terhadap bahasa Bali. Bahasa Bali 
diklasifikasikan menjadi tiga ragam, yakni kode kasar, kode biasa, dan kode alus, sehingga sikap yang dimaksudkan pun dibedakan menjadi tiga, yakni sikap terhadap kode kasar, sikap terhadap kode biasa, dan sikap terhadap kode alus.

\section{METODE}

Penelitian ini mengunakan desain survei yang diterapkan secara deskriptif. Desain survei merupakan suatu desain penelitian kuantitatif yang mana "peneliti mensurvei sejumlah sampel atau seluruh populasi untuk melukiskan sikap, opini, perilaku dan karakteristik populasi tersebut" (Creswell, 2008: 388). Umumnya, survei itu dilakukan dengan menggunakan angket. Setelah data diperoleh, hasilnya dipaparkan secara deskriptif, yakni suatu pemaparan atau penggambaran atas fakta-fakta, klasifikasi, dan hubungan antara fenomena yang dikaji secara sistematis dan akurat.

Penelitian ini dilaksanakan di enam kelurahan di Kota Singaraja, yaitu Sukasada, Liligundi, Banjar tegal, Banyuasri, Banyuning dan Penarukan yang penduduknya mayoritas adalah penduduk asli.

Populasi penelitian ini adalah masyarakat tutur bahasa Bali di Kota Singaraja yang merasakan dirinya memiliki keanggotaan primer pada guyub tersebut. Jumlah populasi penduduk Kota Singaraja menurut sensus penduduk tahun 2008 adalah 80747 jiwa, yang tersebar di 19 kelurahan. Jumlah populasi tersebut dikurangi lagi menurut umur, karena yang menjadi populasi dari penelitian ini adalah dari umur 20 tahun ke atas menjadi sekitar 56.614 jiwa. Jumlah itu tidak dikurangi lagi dengan jumlah pendatang atau penutur bukan asli Kota Singaraja karena kurangnya data sehingga populasi dari penelitian ini dianggap berjumlah 56.614 jiwa (orang). Penentuan jumlah sampel dilakukan dengan menggunakan tabel Fowler (lihat Creswell, 2008) dengan menggunakan taraf kepercayaan 95\%. Dengan menggunakan tabel tersebut didapatkan bahwa jumlah sampel yang diperlukan adalah 300. Akan tetapi, di dalam realitas jumlah sampel yang dipilih adalah 285 karena responden dengan karakteristik sosial yang berstatus kerja tinggi tidak dapat diperoleh sejumlah yang diinginkan. Meskipun demikian, jumlah 285 dianggap sudah mencukupi karena populasi diasumsikan memiliki tingkat kehomogenan tinggi.

Populasi selanjutnya dibedakan menurut lapisan wangsa, status pekerjaan, umur, dan gender. Dari populasi tersebut, sampel diambil melalui disproportionate stratified purposive sampling 'sampel nonacak berlapis-takproporsional'. Metode penarikan sampel ini digunakan karena populasi itu berlapis secara sosial menurut wangsa, status pekerjaan, umur, dan gender, dan informasi data tentang proporsi lapisan tersebut tersebut tidak diketahui. Selain itu, responden juga dipilih secara purposif karena responden yang dipilih hanya yang bersedia saja. Selanjutnya, satu responden pada setiap sel diambil satu secara nonacak untuk diwawancarai.

Jurnal IImu Sosial dan Humaniora |640 
Instrumen penelitian yang diterapkan pada penelitian ini adalah angket yang disusun dengan menggunakan skala likert. Skala likert lazim digunakan untuk mengukur sikap, pendapat, persepsi seseorang terkait dengan fenomena sosial tertentu (Riduwan, 2010:86). Pada skala likert variabel yang diukur dijabarkan menjadi dimensi, selanjutnya menjadi variabel, dan kemudian subvariabel. Dari subvariabel inilah indikator-indikator dari pernyataan pada skala likert disusun. Angket skala likert pada
penelitian ini disusun dengan memperhatikan komponen sikap, yakni komponen kognitif, komponen afektif, dan komponen konatif; dimensi sikap bahasa, yakni kesetiaan bahasa, kebanggaan bahasa, dan kesadaran akan norma penggunaan bahasa; dan tingkat tutur, yakni sikap terhadap kode kasar, sikap terhadap kode biasa, dan sikap terhadap kode alus. Untuk lebih jelasnya, lihat kisi-kisi angket pada tabel 1 yang menunjukkan komponen sikap, dimensi sikap bahasa, aspek dari bahasa Bali, dan jumlah pernyataan.

Tabel 1 Kisi-kisi Sikap Bahasa

\begin{tabular}{|c|c|c|c|c|c|c|c|c|c|}
\hline \multirow{2}{*}{$\begin{array}{l}\text { Dimensi Sikap } \\
\text { Bahasa } \\
\text { Komponen } \\
\text { Sikap }\end{array}$} & \multicolumn{3}{|c|}{$\begin{array}{c}\text { Kesetiaan } \\
\text { Bahasa }\end{array}$} & \multicolumn{3}{|c|}{$\begin{array}{c}\text { Kebanggaan } \\
\text { Bahasa }\end{array}$} & \multicolumn{3}{|c|}{$\begin{array}{c}\text { Kesadaran } \\
\text { akan Norma } \\
\text { Penggunaan } \\
\text { Bahasa }\end{array}$} \\
\hline & KK & $\mathrm{KB}$ & $\mathrm{KA}$ & KK & $\mathrm{KB}$ & $\mathrm{KA}$ & $\mathrm{KK}$ & $\mathrm{KB}$ & $\mathrm{KA}$ \\
\hline Kognitif & 3 & 3 & 3 & 3 & 3 & 3 & 3 & 3 & 3 \\
\hline Afektif & 2 & 1 & 1 & 2 & 2 & 4 & 5 & 4 & 6 \\
\hline Konatif & 2 & 2 & 2 & 3 & 3 & 2 & 2 & 2 & 2 \\
\hline
\end{tabular}

Keterangan:

$\mathrm{KK}$ : kode kasar; KB: kode biasa; dan KA: kode alus

Tabel 1 menunjukkan bahwa total pernyataan pada angket adalah 78 yang digunakan untuk mencari tingkat kesetujuan responden yang terdiri atas sangat tidak setuju (STS), tidak setuju (TS), netral (N), setuju (S) dan sangat setuju (SS). Selain angket, pedoman wawancara juga digunakan. Pedoman wawancara itu terdiri atas pertanyaanpertanyaan terbuka untuk mengetahui dan melengkapi data-data yang diperoleh melalui angket.
Untuk menganalisis hasil angket skala, sikap peneliti terlebih dahulu menentukan sifat dari pernyataan sikap untuk menentukan skor sikap secara kuantitatif. Pada pernyataan positif, jawaban sangat setuju diskor 5 , setuju 4 , netral 3, tidak setuju 2, dan sangat tidak setuju 1. Sebaliknya, pada pernyataan negatif, jawaban sangat tidak setuju diskor 5, tidak setuju 4, netral 3, setuju 2, dan sangat setuju 1.

Berbeda dengan analisis hasil angket, hasil wawancara pertama-tama dikelompokkan menjadi pola-pola,

Jurnal IImu Sosial dan Humaniora |641 
kategori-kategori atau tema-tema menurut respons yang oleh responden terkait dengan pertanyaan yang diberikan oleh peneliti. Respons beragam terkait dengan pertanyaan mengenai sikap terhadap kode kasar, misalnya, diklasifikasikan, dan dikategorikan menurut respons yang diberikan. Respons yang sama dikelompokan pada klasifikasi yang sama, sedangkan respons yang berbeda dikelompokkan pada klasifikasi yang berbeda. Respon terklasifikasi tersebut selanjutnya digunakan untuk memperkuat temuan yang diperoleh melalui angket.

\section{HASIL DAN PEMBAHASAN Hasil Angket}

Persentase rerata sikap bahasa masyarakat tutur bahasa Bali Kota Singaraja dapat dilihat pada tabel 2 berikut.

Tabel 2. Sikap Bahasa Penutur Triwangsa dan Jaba Guyub Tutur Kota Singaraja

\begin{tabular}{|c|c|c|c|c|c|c|c|c|c|c|c|c|c|}
\hline NO & $\begin{array}{c}\text { KELOM- } \\
\text { POK }\end{array}$ & KK1 & KK2 & KK3 & KK 4 & KB1 & KB2 & KB3 & KB4 & $\mathrm{KA} 1$ & KA2 & KA3 & KA4 \\
\hline 1 & TTDL & 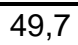 & 7,7 & 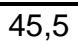 & 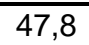 & 7,8 & 67 & - & 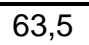 & - & 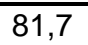 & 74 & 2,1 \\
\hline 2 & TTDP & (1) & 45,4 & 42,2 & 40,0 & 65,1 & 64,1 & 50,5 & 0,7 & 9,3 & & 74,3 & 2,6 \\
\hline 3 & TTML & 50,2 & 45,7 & 38,8 & 45,4 & 63,4 & 58,8 & 49,4 & 58,2 & 83,1 & 80,5 & 78 & 80,8 \\
\hline 4 & TTMP & 48,1 & 38,5 & 28,1 & 39,1 & 61,2 & 55,2 & 55,2 & 57,9 & 82,3 & 83,3 & 80 & 82,1 \\
\hline 5 & TSDL & 48,9 & 48,4 & 37,3 & 45,5 & 73,5 & 60,2 & 61 & 66,3 & 89,3 & 35,1 & 72,4 & 83,4 \\
\hline 6 & TSDP & 46,3 & 44,6 & 34,9 & 42,5 & 72,3 & 55,3 & 59,4 & 63,9 & 89,7 & & 78 & 85,5 \\
\hline 7 & TSML & 44,8 & 42,9 & 33,7 & 41 & 69,9 & 54,3 & 56,1 & 61,7 & 86,4 & 85,3 & 72,7 & 82,6 \\
\hline 8 & TSMP & 45,9 & 43 & 36,3 & 42,2 & 72,9 & 50 & 49,2 & 59,8 & 86,1 & 85,7 & 76,7 & 83,6 \\
\hline 9 & TRDL & 46,8 & 46,2 & 38 & 44,1 & 73,1 & 63,3 & 62,7 & 7,4 & 3 & & & 2,4 \\
\hline 10 & TRDP & 44,4 & 43,2 & 36,9 & 41,9 & 71,6 & 60,6 & 63,1 & 66,1 & 85,9 & 86 & 75,9 & 83,6 \\
\hline 11 & TRML & 46,3 & 45,7 & 38 & 43,8 & 69,1 & 59,8 & 61,2 & 64,3 & 81,3 & & 71,2 & 78,7 \\
\hline 12 & TRMP & & & & & & & & & & & & 79,1 \\
\hline \multicolumn{2}{|c|}{ Rerata } & 47.1 & 44.6 & 37.1 & 43.4 & 69.0 & 59.5 & 56.7 & 62.9 & 85.9 & 83.5 & 75.0 & 82.2 \\
\hline 13 & JTDL & 52 & 45,1 & 36,6 & 45,2 & 80,5 & 73,1 & 70 & 75,5 & 87,4 & & 69,4 & 77,3 \\
\hline 14 & JTDP & 45,8 & 43,1 & 35 & 41,8 & 80,5 & 74,6 & 67,5 & 75,2 & 82,8 & & 70 & 76,1 \\
\hline 15 & JTML & 50,7 & 47,4 & 43,8 & 47,6 & 79,1 & 71,9 & 67,6 & 73,9 & 79,7 & & 6,2 & 72,9 \\
\hline 16 & JTMP & 47,8 & 45,6 & 46,4 & 46,6 & 76,8 & 73,6 & 65 & 72,6 & 78 & 71,8 & & 72,5 \\
\hline 17 & JSDL & & 48,9 & 43,7 & 49,1 & 79,2 & 73,1 & 71 & 75,2 & 78,6 & & & 74,4 \\
\hline 18 & & & 45,6 & 39 & & 79 & 74,5 & & 74,5 & & & & 78,8 \\
\hline 19 & JSML & 55,6 & 50,5 & 44,1 & 50,5 & 77,4 & 73,7 & 63,9 & 72,6 & 74,4 & 73 & 62,7 & 71,1 \\
\hline 20 & JSMP & 49,4 & 44 & 40 & 44,8 & 74,5 & 72,2 & 60,8 & 70,1 & 75,4 & 72,2 & 63,9 & 71,3 \\
\hline 21 & JRDL & 56,8 & 56,8 & 51,2 & 55,3 & 83,5 & 79,8 & 70,6 & 78,9 & & & 69,8 & 73,8 \\
\hline 22 & JRDP & 53,2 & 53,2 & 47,6 & 51,6 & 81,9 & 76,5 & 69,2 & 76,9 & 73,6 & 72,5 & 71,4 & 72,6 \\
\hline 23 & JRML & 56,2 & 56,8 & 49,4 & 54,5 & 82,7 & 80,2 & 70,4 & 78,6 & 73,6 & 70,1 & 63,7 & 69,7 \\
\hline 24 & JRMP & 51 & 51,9 & 43,9 & 49,3 & 77,9 & 75,1 & & 73,5 & 72,3 & 70,5 & 65,3 & 69,8 \\
\hline & rata & & 49.1 & 43.4 & & & 74.9 & 67.4 & & & & & 73.4 \\
\hline \multicolumn{2}{|c|}{ Rerata total } & 49.4 & 46.8 & 40.3 & 45.9 & 74.2 & 67.2 & 62.0 & 68.8 & 81.9 & 78.3 & 71.1 & 77.8 \\
\hline
\end{tabular}

Keterangan:

KK1: Kode kasar pada komponen kognitif KK2: Kode kasar pada komponen afektif KK3: Kode kasar pada komponen konatif KK4: Rerata persentase pada kode kasar KB1: Kode biasa pada komponen kognitif KB2: Kode biasa pada komponen afektif
KB3: Kode biasa pada komponen konatif KB3: Rerata persentase pada kode biasa KA1: Kode alus pada komponen kognitif KA2: Kode alus pada komponen afektif KA3: Kode alus pada komponen konatif KA4: Rerata persentase pada kode alus 
Secara umum, sikap bahasa guyub tutur Kota Singaraja tergolong baik. Persentase rerata total sikap terhadap kode kasar adalah 45,9 yang dimaknai sebagai netral/sedang; persentase rerata total sikap terhadap kode biasa adalah 68,8 yang dimaknai sebagai positif; dan persentase rerata total sikap terhadap kode alus adalah 77,8 yang juga dimaknai sebagai positif. Berikut adalah paparan mengenai sikap bahasa yang dilakukan menurut poros wangsa, yakni triwangsa dan jaba.

Pada kelompok triwangsa, rerata sikap terhadap kode kasar adalah 43,4 yang berarti netral/sedang; rerata sikap terhadap kode biasa adalah 62,9 yang berarti positif; dan rerata sikap terhadap kode alus adalah 82,2 yang berarti sangat positif. Sikap bahasa pada kelompok triwangsa diuraikan sebagai berikut.

Pada TTDL rerata sikap terhadap kode kasar adalah 47,8 yang berarti netral/sedang, terhadap kode biasa adalah 63,5 yang berarti positif, dan terhadap kode alus adalah 82,1 yang berarti sangat positif; pada TTDP rerata sikap terhadap kode kasar adalah 45,5 yang berarti netral/sedang, terhadap kode biasa adalah 60,7 yang berarti positif, dan terhadap kode alus adalah 82,6 yang berarti sangat positif; pada TTML rerata sikap terhadap kode kasar adalah 45,5 yang berarti netral/sedang, terhadap kode biasa adalah 58,2 yang berarti positif, dan terhadap kode alus adalah 80,8 yang berarti sangat positif; pada TTMP rerata sikap terhadap kode kasar adalah 39,1 yang berarti netral/sedang, terhadap kode biasa adalah 57,9 yang berarti positif, dan terhadap kode alus adalah 82,1 yang berarti sangat positif.

Pada TSDL rerata sikap terhadap kode kasar adalah 45,5 yang berarti netral/sedang, terhadap kode biasa adalah 66,3 yang berarti positif, dan terhadap kode alus adalah 83,4 yang berarti sangat positif; Pada TSDP rerata sikap terhadap kode kasar adalah 42,5 yang berarti netral/sedang, terhadap kode biasa adalah 63,9 yang berarti positif, dan terhadap kode alus adalah 85,5 yang berarti sangat positif; Pada TSML rerata sikap terhadap kode kasar adalah 41 yang berarti netral/sedang, terhadap kode biasa adalah 61,7 yang berarti positif, dan terhadap kode alus adalah 82,6 yang berarti sangat positif; Pada TSMP rerata sikap terhadap kode kasar adalah 42,2 yang berarti netral/sedang, terhadap kode biasa adalah 59,8 yang berarti positif, dan terhadap kode alus adalah 83,6 yang berarti sangat positif.

Pada TRDL rerata sikap terhadap kode kasar adalah 44,1 yang berarti netral/sedang, terhadap kode biasa adalah 67,4 yang berarti positif, dan terhadap kode alus adalah 82,4 yang berarti sangat positif; Pada TRDP rerata sikap terhadap kode kasar adalah 41,9 yang berarti netral/sedang, terhadap kode biasa adalah 66,1 yang berarti positif, dan terhadap kode alus adalah 83,6 yang berarti sangat positif; Pada TRML rerata sikap terhadap kode kasar adalah 43,8 yang berarti netral/sedang, terhadap kode biasa adalah 64,3 yang berarti positif, dan terhadap kode alus adalah 78,7 yang berarti sangat positif; dan Pada TRMP rerata sikap terhadap kode kasar adalah 42,1 yang berarti netral/sedang,

Jurnal IImu Sosial dan Humaniora |643 
terhadap kode biasa adalah 64,6 yang berarti positif, dan terhadap kode alus adalah 79,1 yang berarti positif;

Berbeda dengan sikap pada kelompok triwangsa, pada kelompok jaba rerata sikap terhadap kode kasar adalah 48,5 yang berarti netral/sedang; dan rerata sikap terhadap kode biasa dan kode alus adalah 74,8 dan 77,8 yang berarti positif. Sikap bahasa pada kelompok jaba diuraikan sebagai berikut.

Pada JTDL rerata sikap terhadap kode kasar adalah 45,2 yang berarti netral/sedang, dan terhadap kode biasa dan kode alus adalah 75,5 dan 77,3 yang berarti positif; pada JTDP rerata sikap terhadap kode kasar adalah 41,8 yang berarti netral/sedang, dan terhadap kode biasa dan kode alus adalah 75,2 dan 76,1 yang berarti sangat positif; pada JTML rerata sikap terhadap kode kasar adalah 47,6 yang berarti netral/sedang, dan terhadap kode biasa dan kode alus adalah 73,9 dan 72,9 yang berarti positif; pada JTMP rerata sikap terhadap kode kasar adalah 46,6 yang berarti netral/sedang, dan terhadap kode biasa dan kode alus adalah 72,6 dan 72,5 yang berarti positif.

Pada JSDL rerata sikap terhadap kode kasar adalah 49,1 yang berarti netral/sedang, dan terhadap kode biasa dan kode alus adalah 75,2 dan 74,4 yang berarti positif; pada JSDP rerata sikap terhadap kode kasar adalah 45,3 yang berarti netral/sedang, dan terhadap kode biasa dan kode alus adalah 74,5 dan 78,8 yang berarti positif; pada JSML rerata sikap terhadap kode kasar adalah 50,5 yang berarti netral/sedang, dan terhadap kode biasa dan kode alus adalah 72,6 dan 71,1 yang berarti positif; pada JSMP rerata sikap terhadap kode kasar adalah 44,8 yang berarti netral/sedang, dan terhadap kode biasa dan kode alus adalah 70,1 dan 71,3 yang berarti positif.

Pada JRDL rerata sikap terhadap kode kasar adalah 55,3 yang berarti netral/sedang, dan terhadap kode biasa dan kode alus adalah 78,9 dan 73,8 yang berarti positif; pada JRDP rerata sikap terhadap kode kasar adalah 51,6 yang berarti netral/sedang, dan terhadap kode biasa dan kode alus adalah 76,9 dan 72,6 yang berarti positif; pada JRML rerata sikap terhadap kode kasar adalah 54,5 yang berarti netral/sedang, dan terhadap kode biasa dan kode alus adalah 78,6 dan 69,7 yang berarti positif; pada JRMP rerata sikap terhadap kode kasar adalah 49,3 yang berarti netral/sedang, dan terhadap kode biasa dan kode alus adalah 73,5 dan 79,8 yang berarti positif.

\section{Hasil Wawancara \\ Hasil Wawancara pada Triwangsa}

Hasil wawancara yang dilakukan terhadap responden triwangsa juga menunjukkan hal yang sama seperti pada angket. Responden triwangsa cenderung untuk memiliki sikap yang netral/sedang terhadap kode kasar, positif terhadap kode biasa, dan sangat tinggi terhadap kode alus. Dalam kaitannya dengan kode kasar, walaupun responden triwangsa cenderung untuk meragukan bahwa kode itu akan bertahan karena perkembangan zaman, pergaulan global, dan pentingnya perilaku hormat, mereka juga menyadari bahwa di Kota Singaraja kode kasar telah memperoleh tempat yang cukup 
stabil. Sehingga, untuk tahun-tahun ke depan kode kasar dipercaya akan masih tetap ada.

Responden triwangsa juga mengungkapkan bahwa kode kasar tidak perlu dibina karena penutur umumnya bisa sendiri dengan jalan memungut kosa kata kasar di masyarakat, apalagi kosa kata kasar jumlahnya tidak banyak. Selain itu, mereka juga mengungkapkan bahwa kode kasar tidak seharusnya di beri tempat di media masa, seperti surat kabar atau televisi, karena hal itu kurang mendidik dan dapat menimbulkan salah paham. Meskipun demikian, pada situasi-situasi yang tidak resmi dan diwarnai oleh nuansa keakraban yang tinggi penggunaan kode itu tidak menjadi masalah, bahkan kode kasar yang digunakan pada saat itu akan terkesan biasa dan dapat mempererat keakraban.

Responden triwangsa akan berupaya untuk tidak menggunakan kode kasar karena itu dapat menyakiti atau membuat marah orang lain. Namun, jika ada seseorang menggunakan kode kasar kepada mereka, mereka tidak akan langsung marah. Mereka akan melihat siapa yang berbicara dulu dan mengapa. Jika yang berbicara bermaksud untuk merendahkan, mereka akan menegur keras penutur tersebut Akan tetapi, jika tidak mereka cukup dapat memaklumi walaupun dengan sedikit jengkel.

Sikap responden triwangsa terhadap kode biasa lebih baik dari sikap terhadap kode kasar. Responden itu yakin bahwa kode biasa tidak akan punah karena sebagian besar penutur di Kota Singaraja menggunakan kode itu. Tetapi, bagi mereka kode biasa tidak perlu untuk dibina karena anak-anak dapat mempelajari kode itu sendiri di lingkungan bermainnya. Mereka juga cukup setuju jika kode biasa diberi tempat di media masa untuk membicarakan topik-topik tertentu karena rasa dari kode itu sesungguhnya cukup netral.

Responden triwangsa terutama yang berumur tua sesungguhnya kurang suka jika diajak bercakap-cakap dengan kode biasa karena kode itu tidak mengungkapkan rasa hormat, melainkan solidaritas. Tetapi, jika mereka diajak bercakap-cakap dengan kode biasa, mereka dapat merespons balik dengan kode yang sama. Jadi, Namun, walaupun mereka kurang suka, mereka memahami bahwa kode biasalah yang dianggap menjadi ciri bagi penutur bahasa Bali masyarakat Kota Singaraja secara umum.

Sebaliknya, responden triwangsa memiliki sikap yang sangat positif terhadap kode alus. Responden triwangsa sangat yakin bahwa kode itu akan tetap lestari karena nilai halus dan hormatnya. Selain itu, kode alus berkembang dengan sangat baik di wilayah Bali lainnya. Mereka juga mengungkapkan bahwa kode alus perlu untuk dibina secara serius karena kerumitan bentuk dan penggunaannya. Kode alus juga perlu untuk diberikan tempat di media masa karena sangat tepat untuk digunakan pada media formal, baik itu untuk keperluan mendidik maupun berbagi informasi.

Responden triwangsa akan berupaya untuk menggunakan kode alus pada setiap kesempatan. Jika ada penutur yang mengajak mereka bercakap-cakap dengan menggunakan kode itu mereka akan merasa sangat 
dihormati dan merasa berkewajiban untuk menggunakan kode yang sama.

\section{Hasil Wawancara pada Jaba}

Hasil wawancara yang dilakukan terhadap responden jaba juga menunjukkan hal yang sama seperti pada angket. Responden jaba memiliki sikap yang netral/sedang terhadap kode kasar, dan positif terhadap kode biasa dan kode alus. Dalam kaitannya dengan kode kasar, responden jaba yakin bahwa kode itu akan bertahan menghadapi situasi perkembangan zaman dan pergaulan global karena kode itu memiliki fungsinya sendiri, yakni untuk mengungkapkan kekesalan dan menunjukkan keakraban yang lekat. Berbeda dengan fungsinya di dalam membangun keakraban, penggunaan kode kasar untuk mengungkapkan kekesalan sebaiknya dipikirkan secara matang karena kode kasar yang digunakan untuk itu sungguh-sungguh sangat melukai perasaan. Sehingga, mereka kurang menyarankan pemakaiannya sebagai ungkapan kekesalan.

Responden jaba juga sepakat bahwa kode kasar tidak perlu dibina karena penutur umumnya bisa sendiri dengan jalan memungut kosa kata kasar di masyarakat, apalagi kosa kata kasar jumlahnya tidak banyak. Selain itu, mereka juga mengungkapkan bahwa kode kasar tidak seharusnya di beri tempat di media masa, seperti surat kabar atau televisi, karena hal itu kurang mendidik dan dapat menimbulkan salah paham.

Berbeda dengan kode kasar, sikap responden jaba terhadap kode biasa dan kode alus positif. Responden jaba sepakat bahwa kode biasa dan kode alus tidak akan pernah punah karena kedua kode itu digunakan secara cukup intensif: kode biasa digunakan di antara penutur jaba, sedangkan kode alus digunakan di antara penutur triwangsa. Selain itu, mereka juga menyadari bahwa kode alus digunakan dengan intensitas yang tinggi di wilayahwilayah Bali yang lainnya terutama di Bali selatan. Mereka juga merasa bahwa pembinaan terhadap kode biasa tidak perlu dilakukan karena anak-anak dapat belajar sendiri di lingkungannya, tetapi pembinaan terhadap kode alus perlu untuk dilakukan karena kerumitan dari kode alus itu sendiri.

Walaupun responden jaba cenderung untuk memilih penggunaan kode biasa untuk bercakap-cakap, tetapi jika mitra tutur mereka menggunakan kode alus, mereka juga akan menanggapi balik dengan kode alus. Mereka memahami bahwa pola umum di Kota Singaraja adalah pola egaliter yang ditandai oleh penggunaan kode biasa, tetapi ada juga sekelompok penutur tertentu -triwangsa atau pendatang dari wilayah Bali yang lainnya -menggunakan kode alus untuk menandai hormat. Sebagai akibatnya, pola penggunaan bahasa yang dibayangkan oleh responden jaba adalah pola penggunaan simetris antara kode biasa atau kode alus.

Berdasarkan analisis pada temuan yang dipaparkan di atas, sikap bahasa masyarakat tutur bahasa Bali Kota Singaraja dapat dinyatakan berbeda menurut wangsa, dan tidak menurut status pekerjaan, umur, dan gender, seperti ditunjukkan oleh kategori persentase. Namun, perbedaan itu tidak meliputi semua ragam dari tingkat tutur bahasa Bali kecuali sikap terhadap kode 
alus. Penutur triwangsa dan jaba memiliki kategori persentase yang sama terhadap kode kasar, yakni netral/sedang, dan kategori persentase yang sama terhadap kode biasa, yakni positif. Untuk lebih jelasnya, lihat gambar 1 dan 2 berikut ini.

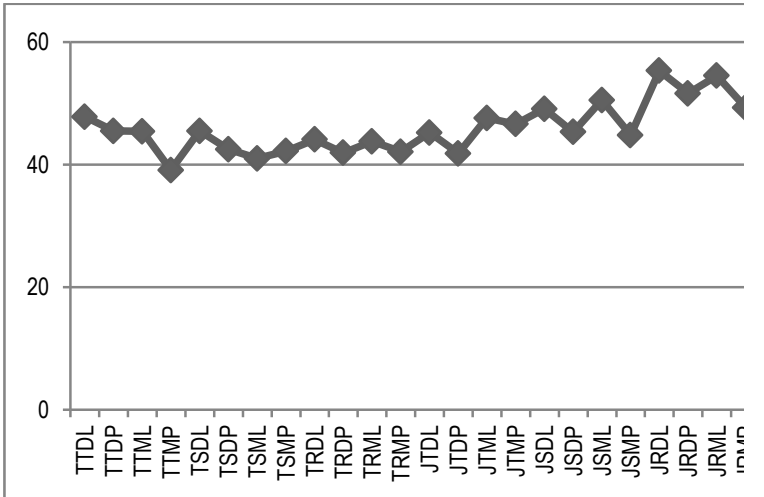

Gambar 1 Sikap terhadap Kode Kasar

Gambar 1 menunjukkan bahwa rerata sikap responden terhadap kode kasar cenderung untuk berada di antara 40-60 yang berarti netral/sedang. Meskipun demikian, persentase sikap terendah ditunjukkan oleh kelompok TTMP dengan persentase 39,1 yang sesungguhnya merupakan sikap negatif; sedangkan persentase tertinggi ditunjukkan oleh JRDL dengan persentase 55,3 yang berkategori netral/sedang.

Sikap netral ini sebenarnya wajar. Pada satu sisi kode kasar secara umum dikesankan kasar yang mengindikasikan ketidaksopanan, tetapi kode itu sering digunakan di kalangan tertentu untuk menandai kedekatan dalam pergaulan. Selain itu, kode kasar juga dianggap perlu digunakan untuk mengungkapkan kekesalan atau ketika berkomunikasi dengan hewan peliharaan. Sehingga, responden terwawancara yakin bahwa kode kasar akan tetap lestari, walaupun penggunaannya di media masa atau pembinaan terhadap kode itu tidak terlalu diinginkan.

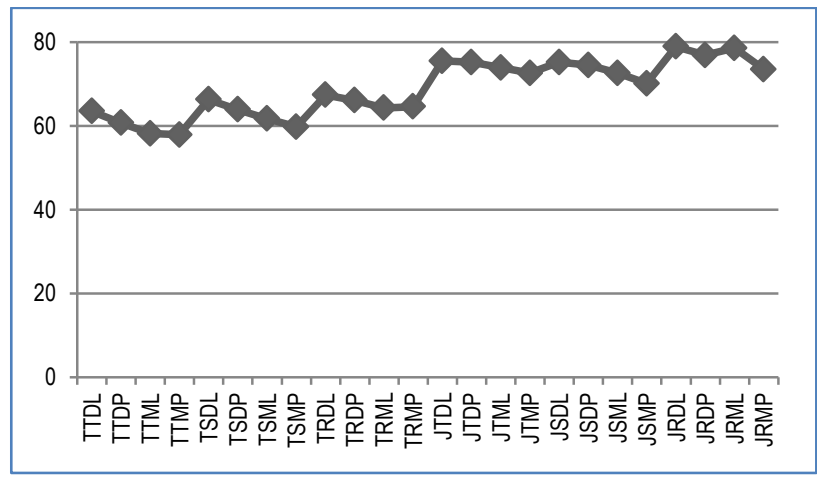

Gambar 2 Sikap terhadap Kode Biasa

Gambar 2 menunjukkan bahwa rerata sikap responden terhadap kode biasa cenderung berada di antara 60-80 yang berarti positif. Meskipun demikian, ada dua kelompok triwangsa, yakni TTML dan TTMP yang menunjukkan kategori sikap netral/sedang dengan persentase 57,9 dan 58,2; sedangkan persentase tertinggi ditunjukkan oleh JRDL dengan persentase 78,9 yang merupakan sikap positif.

Baik responden triwangsa maupun jaba setia, bangga, dan sadar akan norma penggunaan kode biasa. Mereka mengungkapkan bahwa kode biasa yang terkesan netral akan tetap lestari. Mereka juga mengungkapkan bahwa kode itu juga perlu untuk diberikan tempat di media masa walaupun pembinaan terkait kode itu kurang perlu untuk dilakukan. Akan tetapi berbeda dengan harapan responden jaba, responden triwangsa 
tidak berharap agar kode biasa selalu menjadi kode umum di Kota Singaraja.

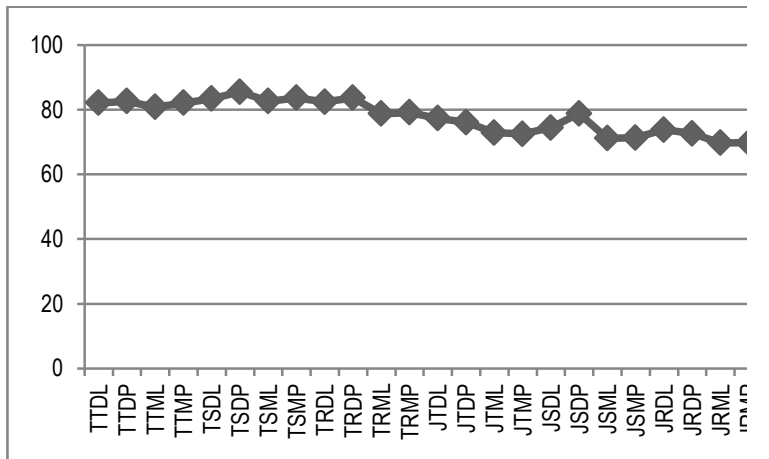

Gambar 3 Sikap terhadap Kode Alus

Gambar 3 menunjukkan bahwa sikap responden terhadap kode alus berada di antara 60-90 yang mana rerata sikap itu berada pada kategori positif. Pada persentase itu, terdapat perbedaan persentase yang cukup mencolok antara triwangsa dan jaba. Sikap yang ditunjukkan oleh responden triwangsa adalah sangat positif, kecuali pada kelompok TRML dan TRMP yang berkategori positif. Sebaliknya, sikap yang ditunjukkan oleh responden jaba secara keseluruhan positif.

Perbedaan intensitas sikap
antara responden triwangsa dan
responden jaba menunjukkan rasa yang berbeda terhadap kode alus. Triwangsa sangat percaya bahwa kode alus akan tetap lestari dan pada waktunya, akan menjadi bahasa umum di Kota Singaraja. Mereka juga mengungkapkan bahwa kode alus adalah kode yang berprestise dan menggambarkan kehalusan penutur bahasanya. Selain itu, mereka juga sangat menginginkan agar pembinaan dan penggunaan kode itu di media masa diintensifkan.
Selain itu, kalau sikap bahasa dianalisis secara cermat dari komponen kognitif sampai komponen konatif terlihat bahwa terdapat penurunan persentase yang signifikan terutama pada responden triwangsa. Sikap terhadap kode kasar pada triwangsa cenderung untuk turun dari kategori netral/sedang menjadi negatif sampai pada komponen konatif, tetapi pada jaba penurunan itu hanya berupa penurunan persentase nonkategori. Sikap terhadap kode biasa pada triwangsa juga cenderung turun dari kategori positif ke kategori netral/sedang, sedangkan pada jaba penurunan sikap itu hanya berupa penurunan persentase nonkategori. Sebaliknya, penurunan kategori persentase sikap terhadap kode alus terjadi baik itu pada triwangsa maupun jaba: pada triwangsa penurunan yang terjadi adalah dari kategori sangat positif ke positif, sedangkan pada jaba dari kategori positif ke netral.

Penurunan kategori itu dari fase kepercayaan ke fase kesukaan sampai ke fase kecenderungan perilaku secara konsisten cenderung untuk meramalkan terjadinya penurunan pada perilaku berbahasa Bali yang nyata. Misalnya, sikap responden triwangsa terhadap kode biasa yang menurun dari positif pada komponen kognitif ke netral/sedang pada komponen konatif mungkin akan dibarengi dengan kecenderungan penggunaannya yang rendah sehari-hari.

Faktor yang dicurigai bertanggung jawab terhadap penurunan itu adalah kehadiran bahasa Indonesia. Bahasa Indonesia telah menjadi kompetitor yang kuat bagi penggunaan bahasa Bali karena bahasa itu memiliki

Jurnal IImu Sosial dan Humaniora |648 
beberapa kelebihan. Pertama, bahasa Indonesia berciri netral sehingga seorang penutur tidak perlu khawatir untuk dikatakan tidak menghormati petutur, asalkan mereka menggunakan istilah sapaan yang sesuai, entah itu Bapak, Ibu, Mbak dan sebagainya. Selain itu, bahasa Indonesia juga dianggap cocok untuk digunakan pada lingkungan perkotaan yang heterogen terkait dengan ciri kesetaraan dan persamaan yang diusung oleh bahasa itu. Keheterogenan wilayah perkotaan di Kota Singaraja terkait dengan komposisi penduduk yang multi etnis karena dulu kota itu dikenal sebagai kota pelabuhan yang ditinggali dan dikunjungi oleh masyarakat multietnis. Terakhir, penggunaan bahasa Indonesia menumbuhkan rasa percaya diri dan modernitas pada penggunanya karena bahasa itu dianggap sebagai bahasa modern dan cocok digunakan untuk membicarakan hal-hal terkait modernitas dan pekerjaan kedinasan tanpa perlu untuk merasa canggung. Siaran TV, surat kabar dan bahkan wawancara kerja juga mensyaratkan kemampuan bahasa Indonesia, sehingga kebutuhan akan bahasa itu menjadi sangat tinggi.

\section{PENUTUP}

Dari paparan di atas diperoleh
simpulan bahwa sikap bahasa
responden cenderung untuk berbeda
menurut wangsa, tetapi tidak menurut status pekerjaan, umur, dan gender. Sikap terhadap kode kasar dan kode biasa pada penutur triwangsa dan jaba cenderung untuk tidak menunjukkan perbedaan, yakni netral/sedang dan positif secara berurutan. Akan tetapi, sikap terhadap kode alus berbeda: pada triwangsa sikap terhadap kode itu berkategori sangat positif, sedangkan pada jaba sikap yang ditunjukkan tergolong positif.

Di samping itu, sikap itu juga menunjukkan penurunan dari komponen kognitif ke konatif terutama pada triwangsa. Penurunan sikap pada triwangsa yang terkait dengan kategori terjadi pada sikap terhadap kode kasar, kode biasa, dan kode alus; sedangkan, pada jaba penurunan itu bersifat nonkategoris kecuali pada sikap terhadap kode alus. Dari penurunan ini dapat diramalkan bahwa penggunaan ragam bahasa Bali secara nyata juga cenderung untuk menurun. Penurunan itu dapat terjadi karena kehadiran bahasa Indonesia yang dianggap memiliki kelebihan karena berciri netral, cocok digunakan di lingkungan kota yang multietnis, dan modern. Dari sini terlihat bahwa terjadi persaingan antara penggunaan bahasa Bali dan bahasa Indonesia.

\section{DAFTAR PUSTAKA}

Azwar, S. 2003.Sikap Manusia: teori dan Pengukurannya. Yogyakarta: Pustaka Pelajar.

Baron, R.A. dan Byrne, D. 2002. Psikologi Sosial: Jilid 1. Edisi Kesepuluh. (Djuwita, R. dkk., Pentj). Jakarta: Penerbit Erlangga.

Creswell, J. W. 2008. Educational Research: Planning, Conducting, and Evaluating Quantitative and Qualitative Research. New Jersey: Pearson Education, Inc.

Fasold, R. 1984. The Sociolinguistics of Society. USA: Basil Blackwell Inc.

Garrett, P. 2010. Attitudes to Language. Cambridge: Cambridge University Press.

Jurnal IImu Sosial dan Humaniora |649 
Katubi. 2010. "Sikap Bahasa Penutur Jati Bahasa Lampung". Dalam Linguistik Indonesia, tahun 28, No 1: 41-45. Jakarta: Masyarakat Linguistik Indonesia

Laksana, I K. D. 2009. Tabu Bahasa: Salah Satu Cara Memahami Kebudayaan Bali. Denpasar: Udayana University Press.

Riduwan. 2010. Metode dan Teknik Menyusun Thesis. Bandung: Alfabeta.
Suastra, I M. 1998. "Speech Levels and Social Change: A Sociolinguistic Study in the Urban Balinese Setting" (Disertasi). Australia: La Trobe University.

Tinggen, I N. 1986. Sor Singgih Basa Bali. Singaraja: Penerbit Rhika Singaraja.

Wingarta, P. S. 2009. Meboya: Kearifan Lokal Buleleng dan Restorasi Nilainya. Yogyakarta: Universitas Gajah Mada. 